\title{
First record of a breeding colony of black-necked stilt Himantopus mexicanus (Aves: Recurvirostridae) in northeastern Brazil
}

\author{
V. O. Lunardi ${ }^{a, b *}$, M. L. A. Mendonça ${ }^{a, b}$, A. P. R. Elias ${ }^{a, b}$ and D. G. Lunardi ${ }^{a, c}$ \\ ${ }^{a}$ Laboratório de Ecologia Evolutiva e Molecular - ECOMOL, Universidade Federal Rural do Semiárido - UFERSA, \\ Campus Mossoró, Av. Francisco Mota, 572, CEP 59625-900, Mossoró, RN, Brazil \\ bPrograma de Pós-graduação em Ecologia e Conservação - PPEC, Universidade Federal Rural do Semiárido - UFERSA, \\ Campus Mossoró, Av. Francisco Mota, 572, CEP 59625-900, Mossoró, RN, Brazil \\ 'Programa de Pós-graduação em Ambiente, Tecnologia e Sociedade - PPGATS, Universidade Federal Rural do \\ Semiárido - UFERSA, Campus Mossoró, Av. Francisco Mota, 572, CEP 59625-900, Mossoró, RN, Brazil \\ *e-mail: lunardi.vitor@ufersa.edu.br
}

Received: November 19, 2014 - Accepted: May 5, 2015 - Distributed: November 30, 2015

(With 2 figures)

The black-necked stilt Himantopus mexicanus (Statius Müller, 1776) is a widely distributed shorebird in the Americas, found between western and southern United States and southwestern Peru, West Indies and northeastern Brazil (Gill and Donsker, 2014; Remsen-Junior et al., 2014). The biology of the species is well-known in the northern hemisphere (see Robinson et al., 1999), but much less so in the south. Reproduction of Himantopus in northeastern Brazil is only known through anecdotal information about a few nests or chicks isolated found (e.g. Azevedo-Junior et al., 2004; Olmos et al., 2005). Like other species of the Recurvirostridae, the black-necked stilt breeds in colonies of dozens of breeding pairs and only occasionally in solitary pairs (see Robinson et al., 1999). The main objectives of this study were record and describe for the first time a breeding colony and the structural variation of the nests of the black-necked stilt in northeastern Brazil.

The study area was the artificial salines of the Apodi-Mossoró Estuary ( $\left.04^{\circ} 57^{\prime} \mathrm{S}, 37^{\circ} 08^{\prime} \mathrm{W}\right)$, in the municipality of Areia Branca, Rio Grande do Norte, Brazil. Shorebird populations of the study area had been monitoring from September 1st 2012 to November 1st 2013. We searched and monitored black-necked stilt nests from May 24th (first nest found) to August 7th 2013 (end of the breeding season), during eight surveys and $24 \mathrm{~h}$ of sampling effort. Surveys in the colony were as brief as possible to avoid disturbance (see Pinho and Marini, 2014), and we measured nests and eggs when adults were away. To describe the breeding colony we recorded: the geographic position of nests using a GPS Garmin ${ }^{\circledR}$, the nest construction material and external and internal diameter, and the egg length and width using a caliper rule $(0.1 \mathrm{~mm}$ precision). The number of eggs and the nest status (under construction, active, abandoned, partially loss or totally loss of eggs) in the colony were registered during the surveys. We used the geographic calculator of the Instituto Nacional de Pesquisas Espaciais (INPE, 2014) to calculate distances between nests, and google $\operatorname{Earth}^{\circledR}$, to estimate the total area occupied by the colony.

The reproductive colony occupied a total area of approximately 105.6 ha and the average distance between nests was $103.1 \mathrm{~m}(\mathrm{SD}=119.1 ; \mathrm{min}=4.4 \mathrm{~m} ; \max =567.6 \mathrm{~m})$. The nests were on the dikes (constructed to control or confine water) of evaporation and crystallization pans of the salina. Five general nest types were observed, based on construction material: nest composed entirely of seashell fragments $(\mathrm{n}=1$ nest), plant materials (Batis $\mathrm{sp}$., Bataceae) ( $\mathrm{n}=1$ nest), salt grains ( $\mathrm{n}=7$ nests), seashell fragments and plant materials $(n=10$ nests), salt grains and plant materials $(\mathrm{n}=11$ nests $)$ and seashell fragments, plant materials and salt grains $(n=5$ nests) (Figure 1$)$. Nests had mean external diameter of $33.2 \mathrm{~cm}(\mathrm{SD}=6.2)$ and internal of $10.9 \mathrm{~cm}(\mathrm{SD}=1.2)$. We recorded a total of 65 eggs, and the modal number of eggs per nest was 4 (mean $\pm \mathrm{SD}=1.8 \pm 1.6)$. Egg length averaged $4.3 \mathrm{~cm}$ $(\mathrm{SD}=0.3 ; \min =3.8 ; \max =4.8)$ and egg width was $3.1 \mathrm{~cm}$ $(\mathrm{SD}=0.1 ; \min =2.9 ; \max =3.3)$. In a survey conducted on July 13th 2013, 40\% of all nests were active and one chick was found (Figure 1). At the end of the breeding season (August 7th 2013) all nests were preyed on and no chicks were found. Domestic dog tracks were seen near of the nests in the colony.

Breeding phenology, plumage of reproductive adults and chick (Figures 1 and 2) and number and dimensions of the eggs were similar to those of black-necked stilt populations the northern hemisphere (review in Robinson et al., 1999). The southernmost populations may have intermediate plumage colors that suggest hybridization with White-backed Stilts (see Olmos et al., 2005; Remsen-Junior et al., 2014), but this plumage color pattern was not observed in the study area. The broad variation of structure and composition matter of nests found in the studied colony was also observed in northern populations (Robinson et al., 1999). The objects used by the black-necked stilt to construct the nests are found nearby (Robinson et al., 1999), and this explains why in the study area (salina) many nests were built of salt.

The loss of natural habitat has led to the reduction of black-necked silt populations. The use of converted wetlands by this shorebird can compensate some of these losses; however, these converted habitats are not as likely as natural habitats to be predator-safe for nesting (Robinson et al., 1999). In this study, all the nests and eggs 


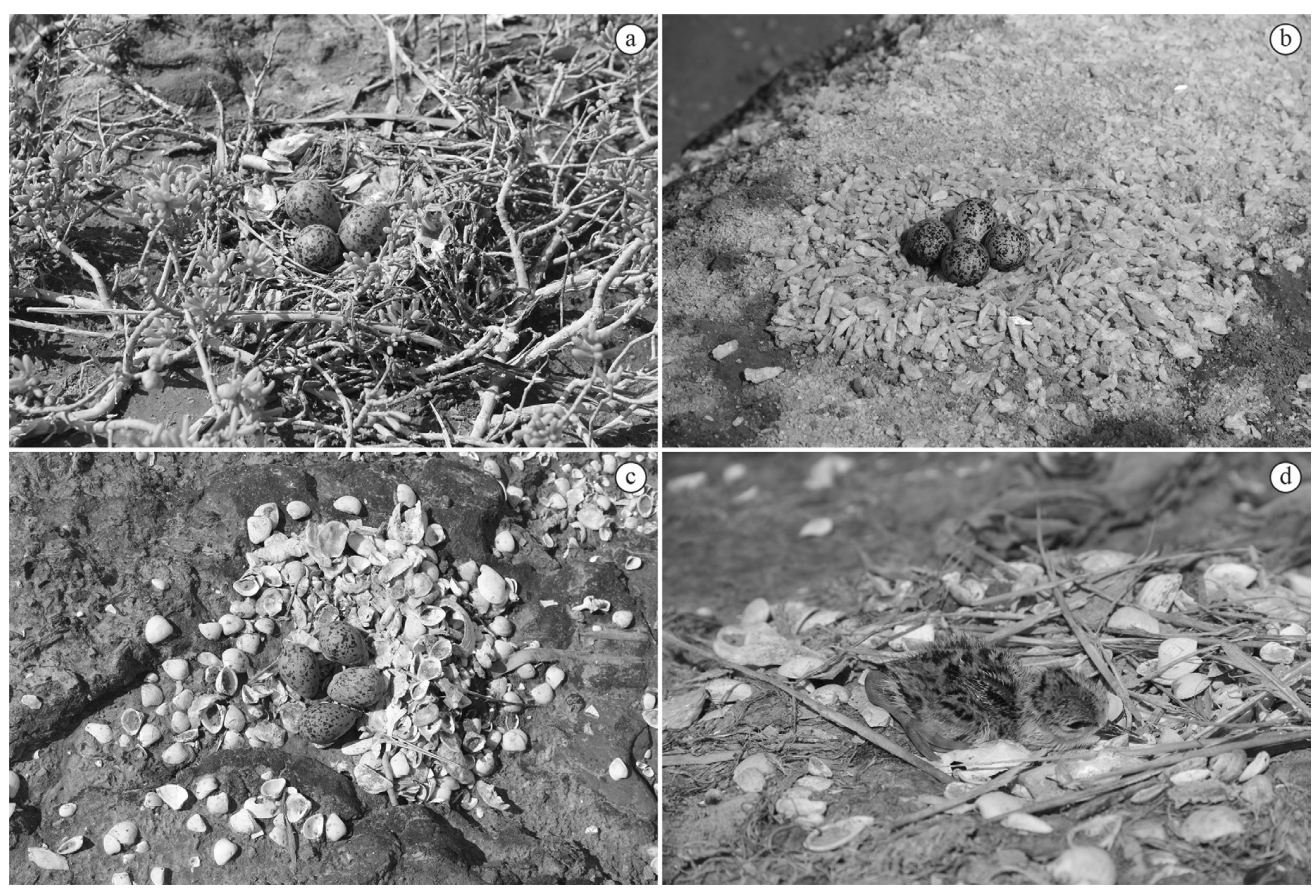

Figure 1. Black-necked stilt nests, eggs and chick at Areia Branca, Brazil. Nest composed of: plant materials and seashell fragments (a, d); salt grains (b); and seashell fragments (c).

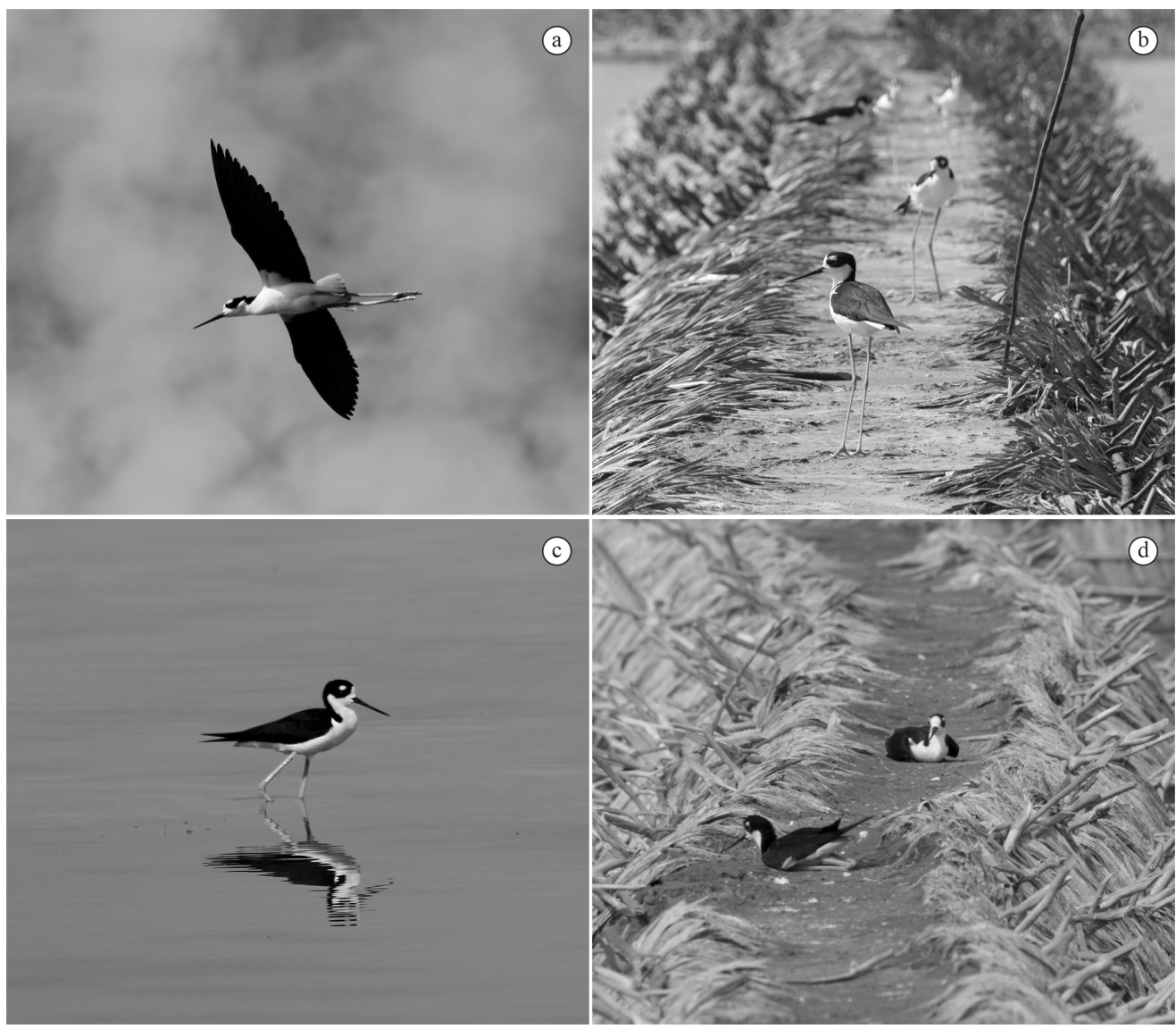

Figure 2. Black-necked stilts in breeding plumage at Areia Branca, Brazil: ventral view (a); dorsal view (b, d); and lateral view (c). 
of black-necked stilt were predated, while in the northern hemisphere, predation rates are about $60 \%$ (review in Herring et al., 2011). The salinas of northeastern Brazil need to be managed (e.g. predator exclusion and removal zones) to reduce the massive nest predation observed in this study.

\section{Acknowledgements}

We thank financial support from the Fundação de Apoio à Pesquisa do Estado do Rio Grande do Norte/FAPERN and the Conselho Nacional de Desenvolvimento Científico e Tecnológico/CNPq, the CIASAL - Indústria Salineira Ltda. for permission to conduct the study.

\section{References}

AZEVEDO-JUNIOR, S.M., LARRAZÁBAL, M.E. and PENA, O., 2004. Aves aquáticas de ambientes antrópicos (salinas) do Rio Grande do Norte, Brasil. In: J.O. BRANCO, ed. Aves marinhas e insulares brasileiras: bioecologia e conservação. Santa Catarina: Editora UNIVALI, pp. 255-266.

GILL, F. and DONSKER, D., eds, 2014 [viewed 18 November 2014]. IOC World Bird List. Version 4.4 [online]. Available from: http://www.worldbirdnames.org.

HERRING, G., ACKERMAN, J.T., TAKEKAWA, J.Y., EAGLESSMITH, C.A. and EADIE, J.M., 2011. Identifying nest predators of American Avocets (Recurvirostra americana) and Black-Necked Stilts (Himantopus mexicanus) in San Francisco Bay, California. The Southwestern Naturalist, vol. 56, no. 1, pp. 35-43. http:// dx.doi.org/10.1894/KF-14.1.

INSTITUTO NACIONAL DE PESQUISAS ESPACIAS - INPE, 2014 [viewed 30 October 2014]. Calculadora geográfica: divisão de processamento de imagens [online]. Available from: http:// www.dpi.inpe.br/calcula/.

OLMOS, F., SILVA, W.A.G. and ALBANO, C.G., 2005. Aves em oito áreas de Caatinga no Sul do Ceará e Oeste de Pernambuco, nordeste do Brasil: composição, riqueza e similaridade. Papéis Avulsos de Zoologia, vol. 45, no. 14, pp. 179-199. http://dx.doi. org/10.1590/S0031-10492005001400001.

PINHO, J.B. and MARINI, M.A., 2014. Birds' nesting parameters in four forest types in the Pantanal wetland. Brazilian Journal of Biology $=$ Revista Brasileira de Biologia, vol. 74, no. 4, pp. 890898. http://dx.doi.org/10.1590/1519-6984.08713. PMid:25627600.

REMSEN-JUNIOR, J.V., CADENA, C.D., JARAMILLO, A., NORES, M., PACHECO, J.F., PÉREZ-EMÁN, J., ROBBINS, M.B., STILES, F.G., STOTZ, D.F. and ZIMMER, K.J., 2014 [viewed 18 November 2014]. A classification of the bird species of South America [online]. American Ornithologists' Union. Available from: http://www.museum.lsu.edu/ Remsen/SACCBaseline.htm.

ROBINSON, J.A., REED, M.J., SKORUPA, J.P. and ORING, L.W., 1999 [viewed 18 November 2014]. Black-necked Stilt (Himantopus mexicanus). In: A. POOLE, ed. The birds of North America [online]. Ithaca: Cornell Laboratory of Ornithology. Available from: http://bna.birds.cornell.edu/bna/species/449. 